\title{
原子間力顕微鏡を利用したナノ力学物性測定技術
}

\author{
谷口幸 範
}

\section{Techniques for Nano-mechanics Measurement using Atomic Force Microscopy}

Yukinori TANIGUCHI (Oxford Instruments KK, 12-20, Tomizawacho, Nihonbashi, Chuo-ku, Tokyo 103-0006)

yukinori.taniguchi@oxinst.com

Controlling domain structure, filler network and their boundary in nanometer and micrometer scale is necessary for development of new generation materials. Not only visualizing their morphology, also quantifying mechanical properties is important for understanding of relationship between molecular structure and bulk properties. This article provides an overview of some techniques for measuring mechanical properties using atomic force microscopy/scanning probe microscopy. Cantilever-based indentation can be used to obtain elastic modulus by assuming contact mechanics. Conventional phase imaging in tapping mode provides information about loss tangent. A bimodal AM-FM technique has advantages for fast and high-resolution imaging of elastic and dissipative properties.

(Received on August 30, 2017)

Key Words : Atomic Force Microscopy, Scanning Probe Microscopy, Indentation, Elasticity, Loss tangent

1. は じ め に

現代の材料は多くの分子種, 無機材料からなる複合材料 である，それらはドメインやネットワークを形成すること によってそれぞれの特性を活かした材料となる。当然それ らの間には界面が形成され，最終的な材料の特性に大きく 関与する. 分子集団が形成するドメイン構造やフィラーの 分散性，それらの界面の性質を制御することが多くの材料 研究開発において中心的な課題になっていることは想像に 難くない.こういった現象はナノからマイクロメートルの スケールで起こり, その正しい姿を知るためには, 種々の 分析手法を組み合わせて迫っていく必要がある。特にナノ 構造を実空間の画像として見るということはSeeing is Believing とも言われるように非常に重要なステップであり, そこから問題解決につながるインスピレーションが得られ ることも多い. そのための道具として, 原子間力顕微鏡 $(\mathrm{AFM}) /$ 走査プローブ顕微鏡 $(\mathrm{SPM})$ ( 以降, 単に AFM とする）は有用である。

\section{A F M の 特 長}

AFMは, カンチレバーとよばれる片持ち梁先端に極微 小な探針をもつプローブでサンプル表面をなぞることによ り, 表面の 3 次元形状を計測する装置として開発された (図1). 空間分解能が非常に高いことが特長であり, 結晶 面等のフラットなサンプルに対しては原子分解能を有す る. 近年, より柔らかい高分子表面でもそれに準ずる分解 能で観察ができるようになってきており，ラメラ結晶表面 での分子鎖レベルの観察例が報告されている ${ }^{1)}$. また, 染 色を必要とせず, 大気中あるいは液中でも測定可能であ り, さらには温度・湿度制御, 雲囲気・溶液の灌流といっ

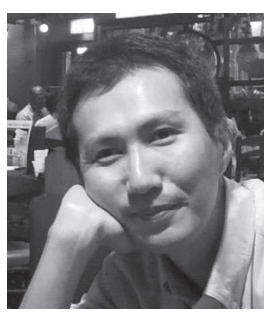

谷口＼cjkstart幸範；オックスフォード・インストゥ ルメンツ侏）アサイラムリサーチ事業部（～ 103-0006 東京都中央区日本橋富沢町12-20日本 橋T\&Dビル) アプリケーションサイエンティ ス卜. 博士 (理学).2004年, 東北大学大学院 理学研究科物理学専攻修了. 2012 年, (株ア开 イラムテクノロジー入社, 会社合併後, 現在 に至る。専門は，AFMを用いた物性評価。 


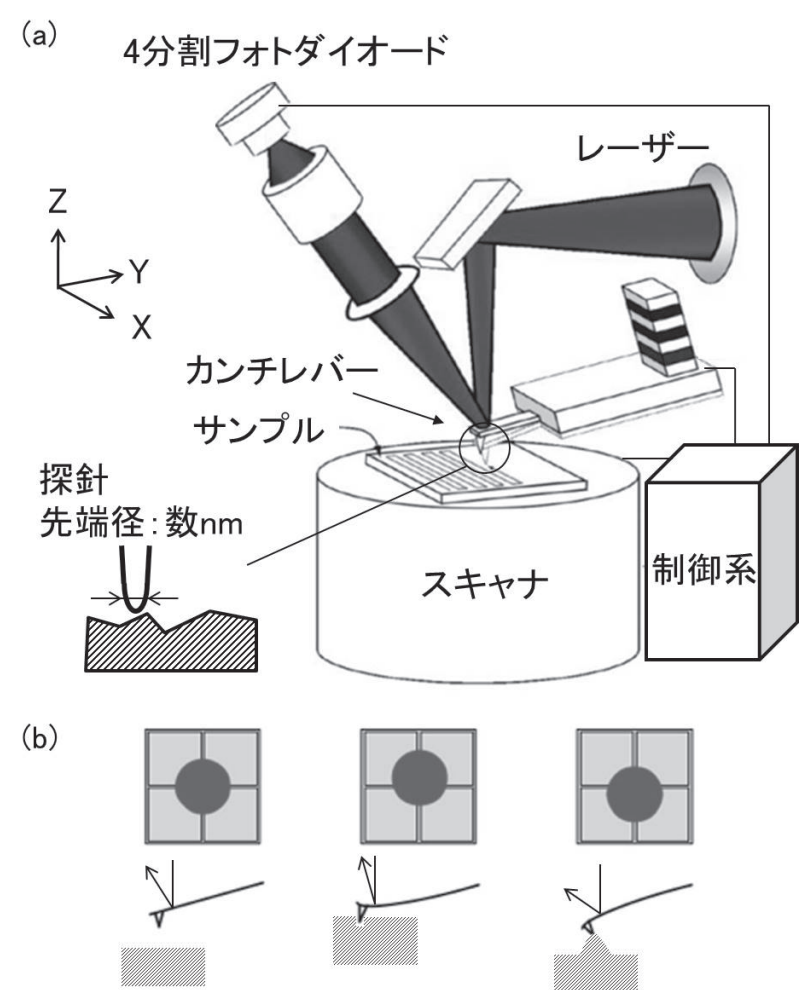

図1 (a) AFM装置の模式図. スキャナ, カンチレバー, カンチレ バーのしなりを検出する光テコ検出系，およびそれらの制御系 （コントローラー, PC) から構成される.（b）光テコの原理. カンチレバーのしなり量をレーザースポット位置の変位として 検出する。しなり量は力に換算できる.

た環境制御，サンプルストレッチステージとの組み合わせ も可能である.

形態観察からもう一歩進んで, カンチレバーで「触れ る」という特長を活かすことにより，粘弾性や摩擦といっ た力学特性，導電性や表面電位といった電気的特性，拈よ び軟化点や熱伝導性等の物性をナノスケールで評価でき る. スクラッチやリソグラフィー等の表面加工的な使い方 も可能である。装置進化の解説は他に譲ることとし ${ }^{2)}$, 本 稿では特にゴム材料との関係が深い力学特性の測定を中心 に最新のトピックを紹介したい，タイヤをはじめ，導電性 ゴム，免震ゴム，建材用ゴム，粘着剂， $\mathrm{ABS}$ 等の樹脂製 品，コーティング剂，塗膜，複合材，バイオ関連材料等の 研究開発・分析等で実績があり，その応用範囲は広い。サ ンプルにはある程度の平坦さが要求され，クライオウルト ラミクロトーム，機械研磨，あるいはクロスセクションポ リッシャーを用いて作製した断面を測定することが多い.

\section{AFMを用いた力学特性の測定}

AFMで測定するのは探針ーサンプル間に働く力である. 探針 - サンプル間には静電気力, ファンデルワールス力, （表面吸着水による）凝着力等の表面力が働く、マクロな スケールではあまり気にならないこれらの力がナノスケー ルでは無視できない影響を及ぼすことに留意が必要であ る。また，サンプルの力学応答には例えばどのくらいの変
形速度，変形量に対してのものなのかにより，粘弾性，弾 塑性，降伏や破壊等，そこには本質的に多くの情報が含ま れている。 その中から弾性率等のサンプルの物性值を抽出 するためにいくつかの測定方法（測定モードとも呼ばれ る）が開発されている. 大きく分けて，カンチレバーでサ ンプルを押し込むフォースカーブと呼ばれる方法と，カン チレバーをその共振で振動させてサンプルを吒き，共振周 波数や振幅の変化から力学物性を求めるロスタンジェント 測定やAM-FMがあり，一長一短がある。AFMで得られ る測定值の多くは探針とサンプルとの接触面積に依存する ので，物性値とするには後述するように接触面積を適切に 見積もる必要がある，それを行わなくとも相対比較は可能 である。 その場合，異なる個体のカンチレバーで取得した デー夕の比較はできない.

\section{1 フォースカーブ/フォースマップ}

フォースカーブではスキャナを一定速度でZ方向に動か してサンプルを押し込み，その時のカンチレバーのしなり 量から力を測定する。 スキャナの動作量からカンチレバー のしなり量を引いたものがサンプルの変形量を表し，これ を横軸にとり，縦軸に力をとったグラフをフォースディス タンスカーブ，または単にフォースカーブと呼ぶ，図 2 (a) では単一成分材料で見られる典型的なフォースカーブ

(a)

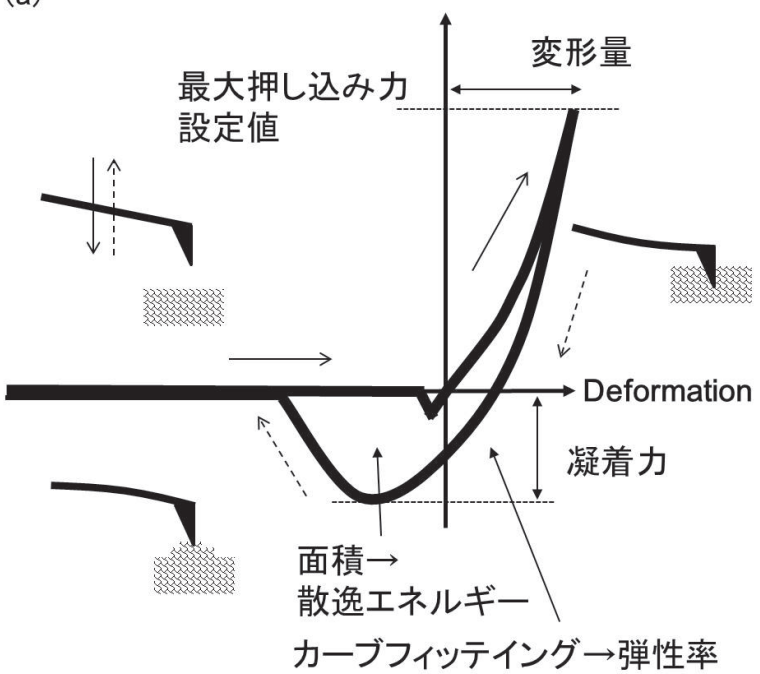

(b)

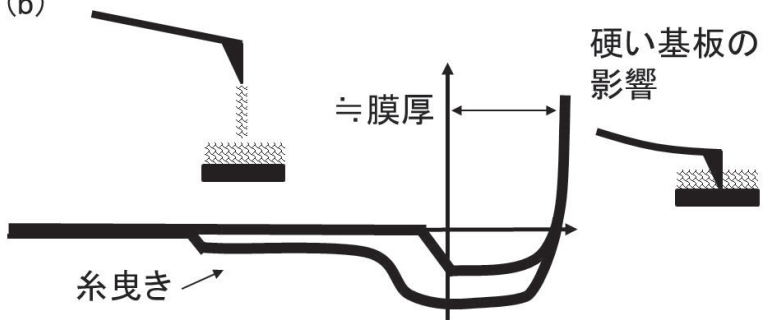

図2（a）典型的なフォースカーブ．スキャナを動かし，カンチレバ 一先端の探針をサンプルへと近づけ押し込む. 力がある設定值 に達したらスキャナを動かす向きを反転させサンプルから引き 離す。（b）硬い基板の上に柔らかい薄膜がある場合のフォース カーブ. 
を模式的に示した，凝着力や，押し达みと引き戻しのカー ブ間の面積から凝着・変形過程で散逸されたエネルギー 量, そしてカーブの形を解析することにより弾性率が求め られる (後述). 図 2 (b) では, 硬い基板の上に非常に柔 らかい薄膜がある場合のフォースカーブを示した. カンチ レバーを押し込み探針が基板に近づくと，その影響でフォ ースカーブが折れ曲がり，さらに押し込まれて基板に到達 するとフォースカーブは垂直に立ち上がる．この間の変形 量をみると大まかな膜厚を知ることができる．また引き戻 し時にテーリングが見られる場合があり，これはサンプル が離れず糸曳きが起こっていることを示している。このよ うに，フォースカーブは多様な使い方ができる.

弾性率を求めるためには探針とサンプルとの接触面積を 知る必要がある。AFMの場合, 実際に触れている面積を 直接見ることができないため, 探針の物理的形状と, コン タクトモデルとを仮定して計算する（図3）。コンタクト モデルには凝着力の程度に応じて Hertz, Derjaguin-Muller-Toporov (DMT), Johnson-Kendall-Roberts (JKR) 等があり，使い分ける必要がある。ゴム材料では 多くの場合 JKR モデルの適用範囲にある ${ }^{3)}$. ポアソン比も 必要なパラメーターである. 解析は弾性変形を仮定してお り，動的な影響や塑性変形は考慮されていない。フォース カーブを測定する際にはできるだけ弾性変形のみ生じるよ うな条件で行うのが望ましい.

サンプルの変形が弾性変形とみなせる押し込み量は限ら れているので, 非常に弱い力と非常に小さい変形量での精 度よい測定と制御が装置に要求される。具体的には，低ノ イズ性に加え, 耐振動性, 低ドリフト性, 低光干渉性とい ったことも含まれる。しばしばスキャナに使用されている ピエゾ素子の非線形性のため, スキャナの動作量が正しく 出力されず，その結果フォースカーブの横軸 (Z位置) が 信頼できない場合がある。これは再現性を悪化させる要因 となるので注意が必要である。ポジションセンサーが搭載 されている装置ではその心配はない，また，精度の良い測

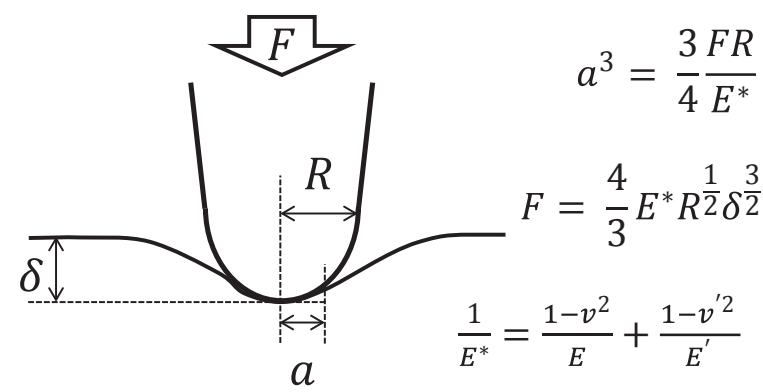

図3 Hertzコンタクトモデル，Fは触圧，Rは探針先端の曲率半径，

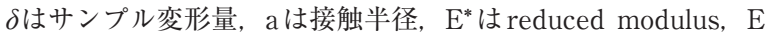
とvはサンプルのヤング率とポアソン比, $\mathrm{E}^{\prime}$ と神はカンチレバ 一材質のヤング率とポアソン比である. Hertzモデルは凝着が ない場合に適用できる。凝着がある場合へと拡張したDMT, JKRモデルもよく用いられる.
定にはサンプルの変形とカンチレバーのしなりが両者とも 適度に起こる必要があり, サンプルの硬さに応じた適切な バネ定数のカンチレバーを選ぶことが重要である.

XY 位置をずらしながら多点でフォースカーブを測定す ることにより各点での物性值をマッピングすることがで き, これはフォースマップ等と呼ばれる. 非常に有用な方 法であるが，測定に時間がかかるという問題がある．例え ばスキャナの Z 動作速度を $1 \mathrm{~Hz}$ で測定する場合, 1 本のフ オースカーブ測定に 1 秒かかり，256×256点のマッピン グを行うと 18 時間もかかってしまう。これをより短時間 で取得すべく, 高速で動作するフォースマッピングモード が開発された。 これは最大数 $\mathrm{kHz}$ での動作が可能であり， $256 \times 256$ 点のマッピングも数分で完了する. ただし，高 速化にあたり各社独自の工夫を加えており, 従来のフォー スマップの完全な上位互換というわけではない。例えばZ スキャナを一定速度ではなく正弦波的に動かす等の違いが 生じている。出てくる值を鵜吞みにせず, 弾性率算出の仮 定が満たされているかに注意が必要である.

\section{2 カンチレバーの共振を利用したカ学物性測定法}

ゴム材料等に対しての形状イメージングはカンチレバー の共振を利用した ACモード（タッピングモード，間欠接 触モード，ダイナミックモード等とも呼ばれる）により行 われる場合が多い.このとき形状情報と同時に, カンチレ バーを励振させる駆動信号とカンチレバーの応答信号との 間の位相遅れの情報が得られる。この位相遅れには探針一 サンプル間の相互作用が反映され，材料の違いに起因する コントラストが得られる場合があることが知られていた。 しかしながら，前述のように探針ーサンプル間の相互作用 には粘弾性だけでなく凝着等が含まれ，また位相の值その ものも測定時のパラメーターに依存して変わることから, 位相からサンプルの物性值を定量的に抽出することは困難 と考えられてきた.

近年, 凝着が無視できるような大振幅での激しいタッピ ング条件ならば，位相遅れと振幅からロスタンジェントを 算出できることが示され ${ }^{4)}$, ゴム材料にも利用され始めて いる. Kepas-Surawaらは天然ゴム (NR) /ブタジエンゴ ム（BR）ブレンドのドメインに関して報告している（図 4) ${ }^{5)}$. GabrielらはNR/BR/カーボンブラック系でバウン ドラバーの研究に利用している ${ }^{6)}$ 。 また, Nguyenらによ り定量性に関する注意点も報告されている ${ }^{7}$.

通常の ACモードイメージング時に, さらに高次の共振 を加えた 2 周波数でカンチレバーを加振し, 形状と弾性率, 散逸エネルギーを同時に测定する方法も開発されている (AM-FMモード $)^{1,8)}$. カンチレバーの共振周波数はカン チレバーの寸法や材質によって決まるが，そこにサンプル との相互作用が加わると, サンプルの主に弾性率に依存し て共振周波数が僅かにシフトする. 高次の共振周波数をイ 
メージング中にリアルタイム計測し, 探針先端形状とコン タクトモデルを仮定した理論式に基づき弾性率を算出す る。また，サンプルの粘性や凝着力によってエネルギーが 散逸する結果, 高次の振幅が減衰する，高次の振幅が一定 になるようにカンチレバーを加振するパワーをフィードバ ック制御し，その時のパワーを記録することによりエネル
ギー散逸量が得られる。高次の共振はどんな種類のカンチ レバーにも存在するので，カンチレバーの種類を問わず利 用することができる。

\section{3 各測定法の長所・短所}

タイヤについて, 共振を用いる AM-FMと, 用いない高 速フォースマップ (FFM) およびフォースマップ (FMap)

$$
\mathrm{T}_{\text {cure }}=130^{\circ} \mathrm{C}
$$

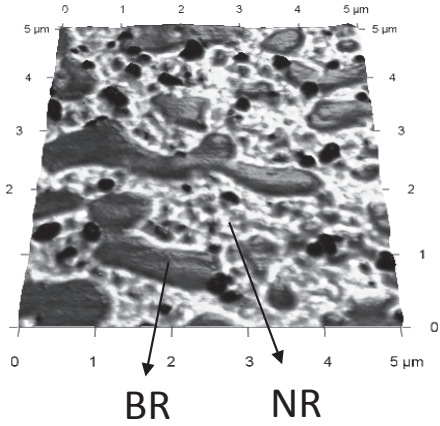

$\mathrm{T}_{\text {cure }}=140^{\circ} \mathrm{C}$

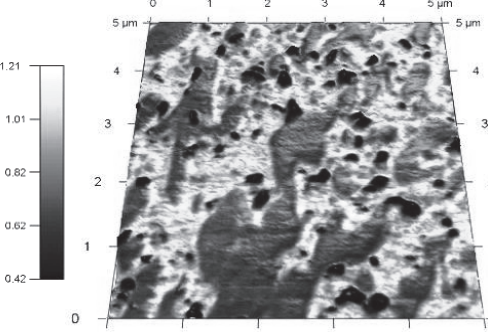

$\mathrm{T}_{\text {cure }}=175^{\circ} \mathrm{C}$

図4 NR/BRブレンドのロスタンジェントマッピング。ロスタンジェント值が 0.9 付近（白）の領域がNR, 0.7 付近（濃い灰色） の領域が BR，ゼロ付近の小さな粒（黒）は酸化亜鉛と考えられる. 加硫温度を変えるとゴムドメインのサイズが変わるもの の, 各ドメインのロスタンジェント值は変わらない。測定周波数は $300 \mathrm{kHz}$ ，文献5）より許可を得て転載.

(a) AM-FM

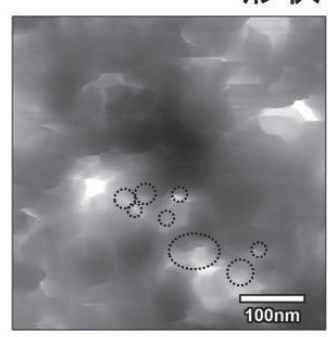

(b) FFM

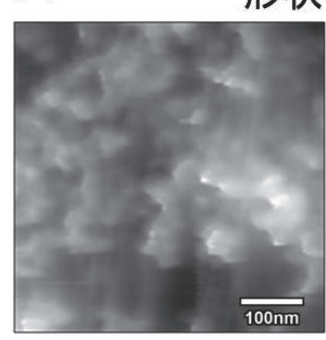

(c) FMap

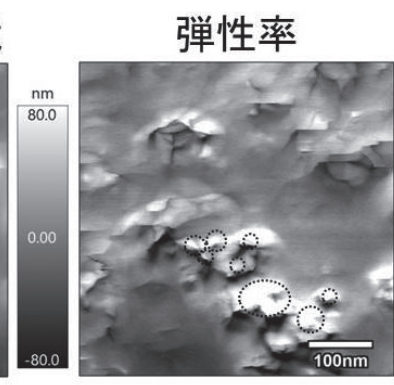

弾性率
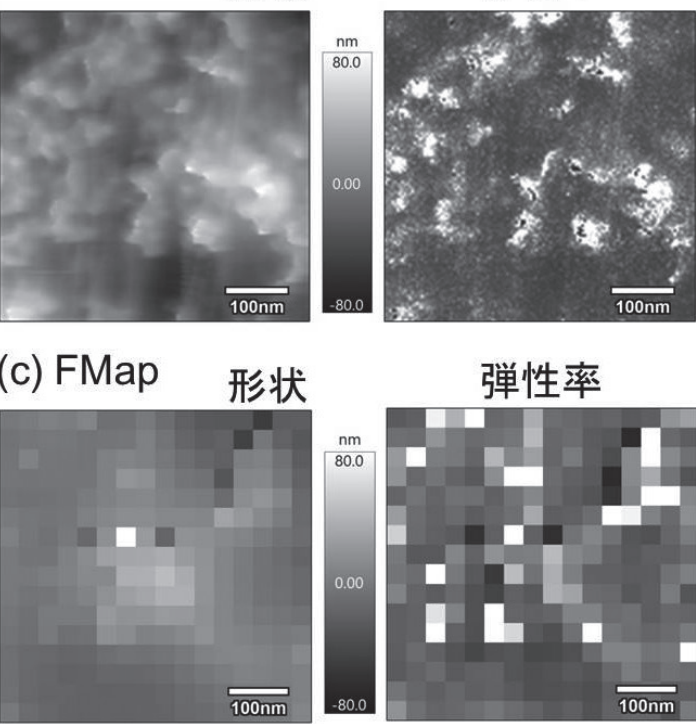

弾性率

形状

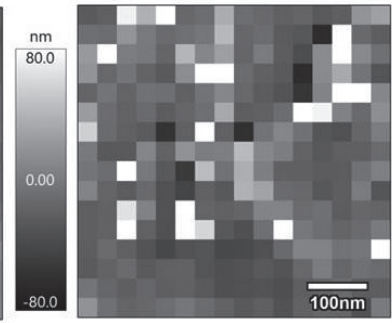

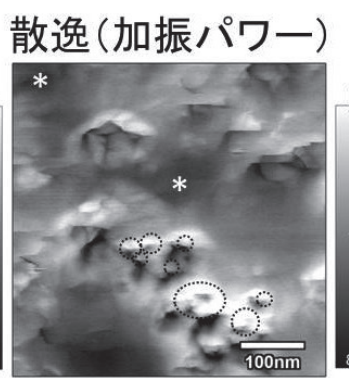

散逸 (面積)

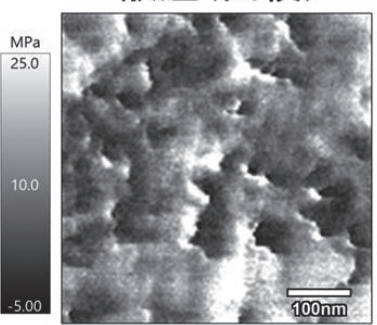

散逸 (面積)

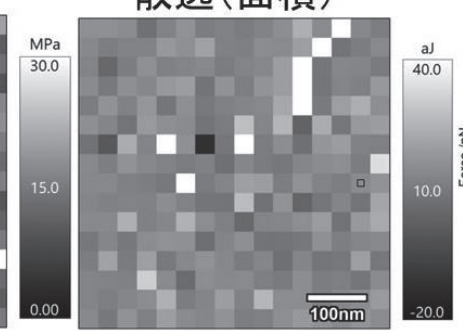

位相

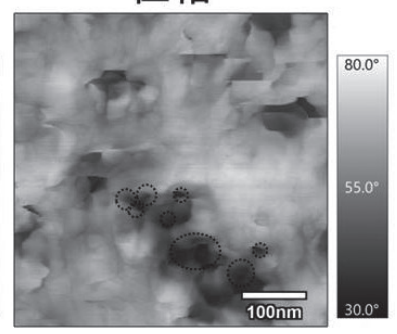

フォースカーブ

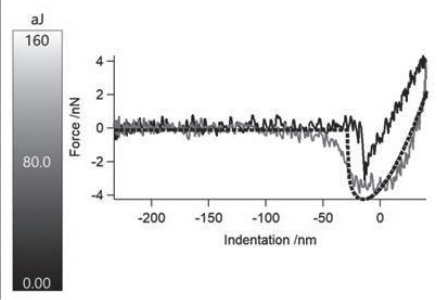

フォースカーブ

図5 ゴムタイヤのカミソリ断面. スキャンサイズはすべて $500 \mathrm{~nm}$ とし, 測定時間が約 4 分になるように測定点数を設定した. (a) AM-FMモード. $512 \times 512$ 点. 位相像からフィラーと思われる部分のうち一部を点線で表示した. フィラー周囲に弾 性率と散逸が大きい領域があるのがわかる。ささらにゴム部の中に散逸が小さい領域が見えている（＊印）。（b）高速フォ ースマップモード $(\mathrm{FFM}) .128 \times 128$ 点. Z動作レートは $170 \mathrm{~Hz}$. フィラーとその周囲が硬く見えている. フォースカー ブ図中の点線はJKR モデルでのフィッティング結果である．（c）フォースマップモード（FMap）１6×16点．Z動作レー トは $1 \mathrm{~Hz}$. 
測定を行った結果を示す (図5)。それぞれの測定時間が4 分となるよう，解像度の調整を行った，AM-FMでは弾性 率像と散逸像でフィラー近傍に硬く, 散逸の大きな境界層 の存在が明瞭に観察されている。FFMはそれに準じる解 像度であり，弾性率の大きな部分が点在している様子がわ かる. FMapの解像度ではフィラーの判別は難しい。弾性 率の值に関しては, $1 \mathrm{~Hz}$ で測定したFMapではカーブの フィッティング結果はJKR モデルと非常によく一致して いるが, FFM（170 Hzで測定）では粘性効果のためモデ ルとの一致はやや劣る. AM-FMでは高次の共振周波数が 約 $1 \mathrm{MHz}$ であることと, 凝着力を考虑に入れていない Hertzモデルで計算しているため，全体的に非常に大きな 弾性率の值が示されている．押し込み深さに関しても各手 法で異なる。AM-FMでは押し込み深さは計算上数 nm 以 下であり，表層のゴム部の情報がよく反映されている。一 方，FMapでは $10 \mathrm{~nm}$ 程度，FFMでは $40 \mathrm{~nm}$ 程度であり， 比較的深いところまで到達している。

共振を利用した AM-FMやロスタンジェント測定のメリ ットはその高いSN比にある。その理由は，1ピクセル分 のデータを取得する間にカンチレバーは何百回もサンプル を吒いており，その平均化された量を見ているからであ る。高いSN 比を活かして高解像度, 高コントラストのイ メージを短時間で得ることができるので，広いエリアに点 在する細かい構造を探索するような目的に向いている．例 えば $1024 \times 256$ ピクセルのイメージを 1 分以内に測定する ことも装置によっては可能である。 また AM-FMはフォー スカーブでは非常に微小な変形しか起こらないような硬い 材料に対しても有効であり，一本のカンチレバーでカバー できる弾性率の測定レンジが広いという利点がある。その 半面, 測定周波数がカンチレバーの共振周波数に決まって しまい，それが非常に高いため，周波数依存性の大きなサ ンプルや，また凝着力が大きいサンプルに対しては現状注 意が必要である。

押し込み深さを変えたい場合にはフォースカーブが簡単 である.フォースカーブではカンチレバーの種類と測定パ ラメーターにより，ある程度自在に押し込み深さを変えら れる. $100 \mathrm{~nm}$ を超えるようなもっと深い押し込み量での 測定も可能である。 ACモードベースのロスタンジェント 測定やAM-FMでは，測定パラメーターを変えてもそれほ ど押し込み媣さは変わらない

今回は紹介していないコンタクト共振等，AFMを用い たナノ力学物性の測定には種々の測定法があるため，それ ぞれの特長を踏まえて目的に合った適切なものを使用する のが望ましい，高速な測定方法で広いエリアをサーベイし た後に，興味あるポイントでフォースカーブを行い $1 \mathrm{~Hz}$ の物性值を求める等，複数の測定方法を組み合わせた使い 方が良いだろう。

\section{4. カンチレバー}

サンプルに直接触れる部分であるカンチレバーは非常に 重要である. カンチレバーは繊細な部品であり, 製造上不 可避なレベルのわずかな厚みの違いによっても，200\%以 上にも及ぶバネ定数のバラつきが生じてしまう。このこと は力学計測の定量性に影響を及ぼす。したがって，個々の カンチレバーについて, その個体のバネ定数を求めておく 必要がある。これにはサーマル法 ${ }^{9)}$, Sader 法 ${ }^{10)}$ 等が用い られる。

もう一つ定量的測定に不可欠な情報が探針の形状であ る. 例えばJKRの解析解は探針を球形とみなしその曲率 半径 Rがパラメーターとなっている. しかし実際の探針は 個体差が大きくカタログ值は参考程度にしかならない. 加 えて，必ずしもきれいな球形ではなく凸凹があることにも 留意しておく必要がある。実効的な $\mathrm{R}$ を求めるためには, 弾性率が既知のサンプルを測定し逆算して求める方法や, 非常に尖った形状をもつチップキャラクタライザーをイメ ージングした結果からブラインド・リコンストラクション により求める方法がある ${ }^{11)}$ 。最終的な弾性率の誤差につい てはバネ定数の測定誤差とも合わせて前者で $10 \%$ 前後, 後者ではそれ以上の誤差が生じ得ると考えておいた方が良 い. 近年では力学測定用として先端に数十 $\mathrm{nm}$ から数 $\mu \mathrm{m}$ まで様々な大きさの球を付けたカンチレバーが市販されて いる. 一般的なイメージング用探針より水平分解能は落ち るものの, 弾性率の定量性にメリットがある.

よく見受けられるのが，測定中に探針が折れて欠損した り，逆に何かが付着してしまったりすることである. どち らも結果に深刻な影響を及ぼすため注意が必要である。こ ういった探針の変化は, 最初のサンプルを再度測定して同 じ值が得られるかどうかで簡単にチェックできるので, サ ンプル間の相対評価を行う際には確かめておくべきであ る. 探針の恒常性を高めるため, 先端にカーボンファイバ 一を付けたものや，探針がダイヤモンドで作られたカンチ レバーが市販されている. 探針の污染を防ぐという意味に おいても，サンプル測定面はできるだけフレッシュに調整 したものがよい. いろいろな条件にもよるが，作製して半 年も経過したサンプルでは表面に容器やテープ由来の污れ が多量に付着しており，形状は測れても物性測定には支障 をきたす．

\section{5. お わ りに}

AFMが市販されるようになりおよそ 30 年が経とうとし ているが，その間 AFMは形状だけでなく物性をマッピン グできる装置として進化を遂げてきた。単に形状を測定す るのに比へ，物性を定量的に測定するためには装置側に要 求されるスペックも高くなる。 それに伴い市販装置も多様 
化し, 数百万円の教育用単機能機から数千万円の高機能か つ操作性を向上させたものまで多くのモデルが販売されて いる. 大学等の研究室レベルでは AFM と動的粘弾性測定 や分光法との組み合わせ等の研究開発 ${ }^{12,13)}$ が行われてお り，AFMを用いたナノ物性評価は現在も発展途上にある といえる.今後の展開にも期待していただきたい.

\section{References}

1 ) Kocun, M.; Labuda, A.; Meinhold, W.; Revenko, I.; Proksch, R.: arXiv, 1702, 06842

2) Ishii, K.: O plus E, 35 (1), 23-24 (2013)

3 ) Nakajima, K.; Liu, H.; Ito, M.; Fujinami, S.: J. Vac. Soc. Jpn., 56 (7), 258-266 (2013)

4 ) Proksch, R.; Kocun, M.; Hurley, D.; Viani, M.; Labuda, A.; Mein hold, W.; Bemis, J.: J. Appl. Phys., 119, 134901 (2016)

5 ) Kepas-Suwara, A.; Cook, S.: Tire Technology International Annual Review, 40-44 (2015)
6 ) Gabriel, D.; Karbach, A.; Drechsler, D.; Gutmann, J.; Graf, K.; Kheirandish, S.: Colloid Polym. Sci., 294, 501-511 (2016)

7 ) Nguyen, HK.; Ito, M.; Fujinami, S.; Nakajima, K.: Macromolecules, 47 (22). 7971-7977 (2014)

8 ) Herruzo, ET.; Perrino, AP.; Garcia, R.: Nat. Commun., 5, 3126 (2014)

9 ) Hutter, JL.; Bechhoefer, J.: Rev. Sci. Instrum., 64, 1868 (1993)

10) Sader, JE.; Sanelli, JA.; Adamson, BD.; Monty, JP.; Wei, X.; Crawford, SA. et al.: Rev. Sci. Instrum., 83, 103705 (2012)

11) Villarrubia, JS.: J. Res. Natl. Inst. Stand. Technol., 102, 425 (1997)

12) Igarashi, T.; Fujinami, S.; Nishi, T.; Asao, N.; Nakajima, K.: Macromolecules, 46 (5), 1916-1922 (2013)

13) Yano, T,; Tsuchimoto, Y.; Mochizuki, M.; Hayashi, T.; Hara, M: Appl. Spectrosc., 70, 1239-1243 (2016)

\section{日本語表記参考文献}

2 ）石井孝治：O plus E， 35 (1)，23-24（2013）

3 ) 中嶋健, 劉浩, 伊藤万喜子, 藤波想 : J. Vac. Soc.Jpn., 56 (7), 258-266 (2013)

* 